\title{
A new Chinese species of Eostrobilops Pilsbry, 1927 with a checklist of Eostrobilops and Enteroplax Gude, 1897 species (Gastropoda, Pulmonata, Strobilopsidae)
}

\author{
Barna Páll-Gergely', András Hunyadi², Takahiro Asami' \\ I Department of Biology, Shinshu University, Matsumoto 390-8621, Japan 2 Adria sétány 10G 2/5., Budapest \\ 1148, Hungary \\ Corresponding author: Barna Páll-Gergely (pallgergely2@gmail.com)
}

Academic editor: Frank Köhler | Received 17 May 2015 | Accepted 6 June 2015 | Published 17 June 2015

http://zoobank.org/E79F84FE-692A-4BF1-9200-D60DC3DE8F9F

Citation: Páll-Gergely B, Hunyadi A, Asami T (2015) A new Chinese species of Eostrobilops Pilsbry, 1927 with a checklist of Eostrobilops and Enteroplax Gude, 1897 species (Gastropoda, Pulmonata, Strobilopsidae). ZooKeys 508: 85-95. doi: 10.3897/zookeys.508.10004

\begin{abstract}
Eostrobilops humicolus Páll-Gergely \& Hunyadi, sp. n. is described from Guangxi Province, China. It is characterized by the combination of a small shell (diameter: 2.3-2.4 mm), strongly ribbed dorsal surface, an infraparietal lamella not reaching the callus, and long basal folds. The new species is found approximately 500 and $800 \mathrm{~km}$ from the two nearest species E. infrequens (northern Vietnam), and E. diodontina (Hunan, China), respectively. A checklist of extant Eostrobilops Pilsbry, 1927 and Enteroplax Gude, 1899 species is provided. Enteroplax yaeyamensis Habe \& Chinen, 1974, Enteroplax kanjiokuboi Minato \& Tada, 1992 and Enteroplax taiwanica Minato \& Tada, 1992 are moved to the genus Eostrobilops because of the lack of an elevated parietal callus and a peripheral thread. A map showing all Eostrobilops records is provided.
\end{abstract}

\section{Keywords}

Revision, taxonomy, systematics, land snail

\section{Introduction}

The family Strobilopsidae is mainly defined on a conchological basis; the shell is trochiform, dome-shaped or discoidal, umbilicate and consists of 4.5-6 slowly increasing whorls. The aperture is oblique, peristome more or less thickened and expanded; the

Copyright Barna Páll-Gergely. This is an open access article distributed under the terms of the Creative Commons Attribution License (CC BY 4.0), which permits unrestricted use, distribution, and reproduction in any medium, provided the original author and source are credited. 
ends of the lips are connected by a parietal callus. The main characteristic feature of the family is the armature consisting of two or three parietal lamellae and several deeplyplaced basal folds, all growing continuously from an early neanic state (Pilsbry 1927). Only four species belonging to two genera have been examined anatomically (Baker in Pilsbry 1935, 1948, Minato 1975, Matsumura and Minato 1998). None of these works revealed anatomical characters that would distinguish the Strobilopsidae from other orthurethran families, such as the Pupillidae and Valloniidae (Manganelli et al. 1989). Strobilopsid DNA sequences were published in two works, but neither of them focussed explicitly on the systematic position of the Strobilopsidae. In the phylogenetic tree of Tongkerd et al. (2004), which focussed on the family Hypselostomatidae, Strobilops labyrinthica (Say, 1817) nested within the valloniid clade. The closest taxon to Strobilops is Zoogenetes harpa (Say, 1824) and two samples of Vallonia costata (O. F. Müller, 1774) formed the sister clade of the Strobilops-Zoogenetes clade. The samples of Pupilla (Pupillidae) and Vertigo (Vertiginidae) were more distantly related to Strobilops than to the members of the Valloniidae. In the phylogenetic tree of Wade et al. (2006), which provided an overview of the phylogenetic relationships between most pulmonate groups, Eostrobilops nipponica (Pilsbry, 1908) clustered with Lauria, Pyramidula and Orcula. In this analysis, Vallonia was only included in the larger, orthurethran clade. These data show that Strobilopsidae is an orthurethran family, but its relationships with other families still require clarification.

Living Strobilopsidae occur in America, from northern Mexico to the northern part of South America, and East Asia, from North Korea and south-eastern Russia to southern Borneo (Pilsbry 1927, Kuroda and Miyanaga 1939, Solem 1968, Miller and Christensen 1980, Schileyko 1984, Vermeulen 1992a,b). Fossil strobilopsids have been reported from Europe, North and South America as well as China (as reviewed by: Wenz 1923, Pilsbry 1927-1935, Manganelli et al. 1989). The oldest fossils that have properly been assigned to the Strobilopsidae dated to the Middle Eocene of Europe. In the New World, fossils no older than from the Late Pliocene can be ascribed to the family. The assignment of Upper Cretaceous-Lower Tertiary Chinese and South American fossils to the Strobilopsidae is speculative only (Manganelli et al. 1989).

Pilsbry (1948) proposed that the family Strobilopsidae had radiated from Asia into Europe and the New World. By contrast, Ferreira and Dos Santos Coelho (1970) believed that South America has been the centre of origin of the family. Solem (1979, 1981) and Manganelli et al. (1989), however, stated that the radiation from a European centre was much easier to explain, especially if the Cretaceous fossils, which are not certainly strobilopsids, were ignored. Solem $(1979,1981)$ mentioned the Strobilopsidae as one of the most interesting cases of "moved" families, i.e. recent families that live far away from the main stock of their fossil records.

East Asia is inhabited by two recent strobilopsid genera: Enteroplax Gude, 1899 and Eostrobilops Pilsbry, 1927, which differ from each other in the morphology of the parietal callus, the edge of the body whorl and the parietal lamellae. Herein, we describe a new species of Eostrobilops from the Chinese province of Guangxi and provide a critically revised checklist of Eostrobilops and Enteroplax species. 


\section{Material and methods}

The nomenclature for the armature follows that of Pilsbry (1927). Scanning electron microscopy was undertaken on uncoated shells under a low vacuum SEM (Miniscope TM-1000, Hitachi High-Technologies, Tokyo). We counted shell whorls (to the nearest quarter of a whorl) following Kerney and Cameron (1979).

Comparative material. Eostrobilops hirasei, Korea, Quelpart (= Cheju Island), det. Zilch (?), NHMUK 1909.2.20.112.114.; Eostrobilops nipponica (labelled as matsushimae), Japan, Uzen, NHMUK 1912.6.28.19-20, NHMUK 1912.6.29.32-34; Eostrobilops coreana, 朝鮮京城府北渓山 (probably Cho-Sen Kei-Joh-Fu, Hoku-KeiZan), Sakurai collection, NSMT/2; Eostrobilops kanjiokuboi, 中華民国 (台湾) 南投 県信義郷東埔楽々温泉, Lo lo uen chuan, Tung-pu, Hsin-i shiang, Nan tou hsien, Taiwan, NSMT 69652/1 paratype; Eostrobilops diodontina, China, Tchen-k'eou, leg. Farges, excoll Musée Heude, 03.01.1946, MCZ, 167133 (photos of a syntype were received from Jochen Gerber). We could not examine most Eostrobilops types during our visit to the National Museum of Nature and Science, Tsukuba, Japan (11-13 March, 2015), because they were on loan. The comparisons of Eostrobilops humicolus sp. n. with E. infrequens and E. triptychus were based on the original descriptions of these species.

\section{Abbreviations}

HA Collection András Hunyadi, Budapest, Hungary

HNHM Hungarian Natural History Museum, Budapest, Hungary

MCZ Museum of Comparative Zoology, Massachusetts, USA

NHMUK The Natural History Museum, London, United Kingdom

NSMT National Museum of Nature and Science, Tsukuba, Japan

\section{Results}

\section{Taxonomic description}

Family Strobilopsidae

\section{Genus Eostrobilops Pilsbry, 1927}

1927 Eostrobilops Pilsbry (as a section of Strobilops), Manual of Conchology, Second Series, 28: 42.

Type species. Strobilops hirasei Pilsbry, 1908, by original designation. 


\section{Eostrobilops humicolus Páll-Gergely \& Hunyadi, sp. n.}

http://zoobank.org/AE9A1A96-A8F8-4E94-B5E7-45A6452ADC20

Material. China, Guangxi (广西), Hechi Shi (河池市), Tiane Xian (天峨県), Qimu Xiang (豈暮鄉), road junction toward Lahaoyan (拉号岩), cliff overlooking a memorial, $600 \mathrm{~m}, 24^{\circ} 51.130^{\prime} \mathrm{N}, 107^{\circ} 11.670$ 'E, leg. Hunyadi, 12.09.2013., HNHM 99419 (holotype, Figure 1A-C), HNHM 99420 (paratype, Figure 1D-E and 2), HA/5 paratypes.

Diagnosis. A small Eostrobilops species with a strongly ribbed dorsal surface, an infraparietal lamella not reaching the callus, and long basal folds.

Description. Shell small, light brown (only one shell in type material had original colour); trochiform, rather domed above, almost flat ventrally (umbilical side), periphery rounded, very slightly keeled, suture rather deep; $4.75(\mathrm{n}=3)$ slowly expanding whorls, protoconch approximately 1.5 whorls; virtually smooth but with weak microscopic pits arranged in irregular radial lines; teleoconch irregularly ribbed; ribs strong dorsally, very weak ventrally (except for inside the umbilicus); spiral structure entirely lacking; umbilicus narrow; inner margin of the whorls exposed in umbilicus irregularly crenulated; aperture semilunar and oblique; peristome slightly thickened and slightly reflexed; parietal callus weak; parietal and infraparietal lamellae well-developed, although the infraparietal does not extend to the peristome; a low interparietal lamella deeply situated, not visible from aperture; three long basal folds and one short columellar lamella; basal folds visible in one specimen with a fresh, translucent shell only (Figs 1D-E, 2). However, this specimen was broken and the fold length can only be estimated (ca. a minimum of a quarter whorl).

Differential diagnosis. Both E. hirasei and E. nipponica are much larger than the new species, they have a more rounded body whorl, wider umbilicus, and weaker dorsal sculpture. Eostrobilops coreana is larger and flatter than E. humicolus sp. n., has a weaker dorsal sculpture, both of its parietal lamellae extend to the peristome, and has a shorter basal folds. Eostrobilops kanjiokuboi is similar to E. humicolus sp. $\mathrm{n}$. by having a strongly ribbed dorsal surface and long basal folds, but differs in the larger size, wider umbilicus, and the serrated lamellae (not serrated in E. humicolus sp. n.); the infraparietal lamella extends to the callus (not in E. humicolus sp. n.), and has a long palatal fold, which is lacking in the new species. Eostrobilops diodontina is slightly larger $(\mathrm{D}=2.88, \mathrm{H}=1.75 \mathrm{~mm})$, has more elevated parietal and infraparietal lamellae, and both lamellae attain the peristome. Moreover, E. diodontina has shorter basal folds. Eostrobilops infrequens has a more elevated spire than E. humicolus sp. n., a stronger callus, a narrower umbilicus and shorter basal folds. The spire of E. triptychus is higher, it has more angulate periphery, thicker peristome and shorter basal folds.

Measurements (in mm): $\mathrm{D}=2.3-2.4, \mathrm{H}=1.45-1.5(\mathrm{n}=2)$.

Etymology. From Latin ('humicolus' = soil-dwelling), in reference to the fact that this species was found in soil samples. 


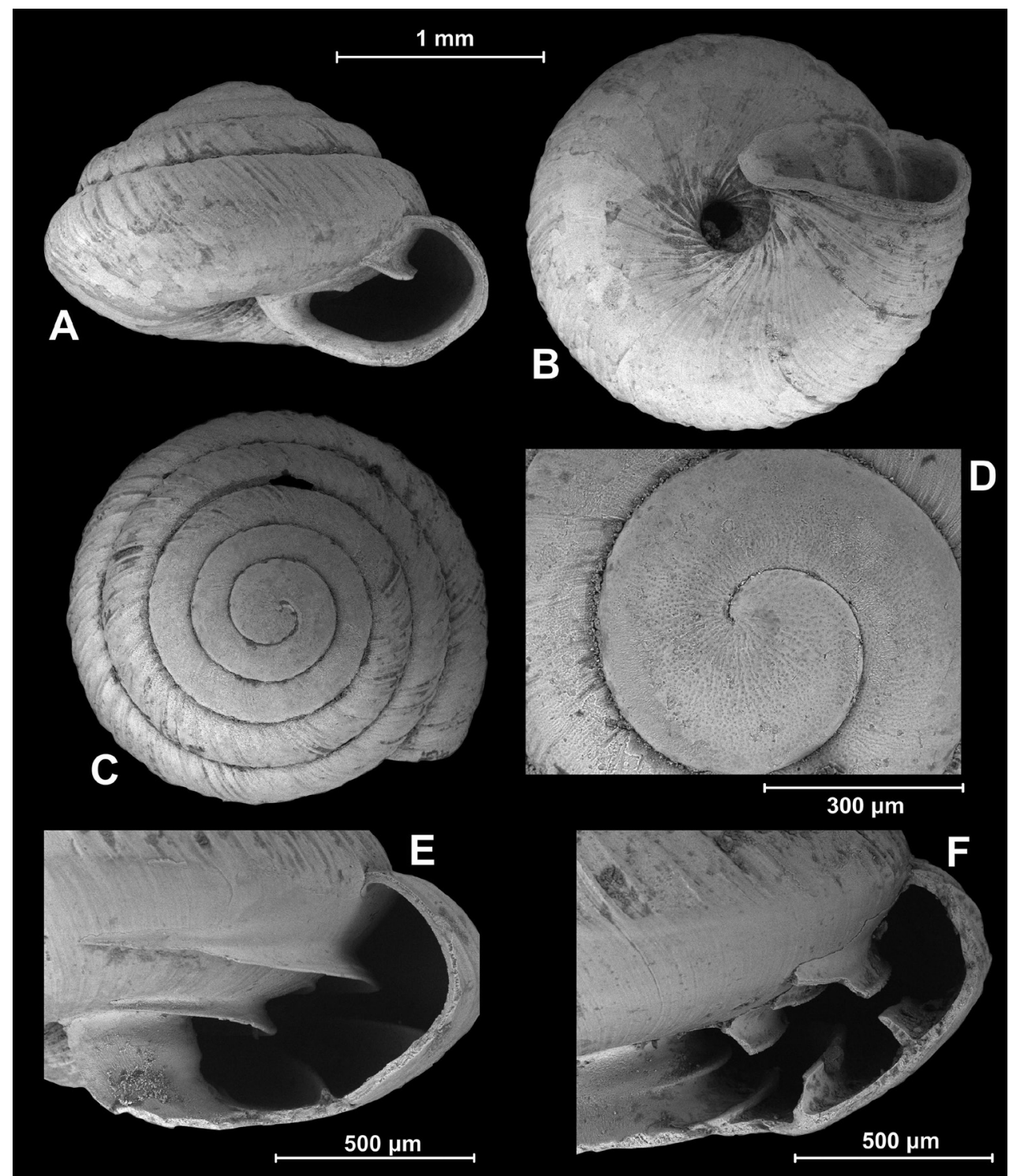

Figure I. SEM images of Eostrobilops humicolus sp. n. A-C holotype D-E paratype1 F paratype2.

Ecology. No living specimens have been found. The empty shells were collected from a soil sample. Eostrobilops humicolus sp. n. probably lives under stones and dead leaves on the soil.

Type locality. China, Guangxi (广西), Hechi Shi (河池市), Tiane Xian (天峨 県), Qimu Xiang (豈暮鄉), road junction toward Lahaoyan (拉号岩), cliff overlooking a memorial, $600 \mathrm{~m}, 24^{\circ} 51.130^{\prime} \mathrm{N}, 107^{\circ} 11.670^{\prime} \mathrm{E}$.

Distribution. Known from the type locality only. 


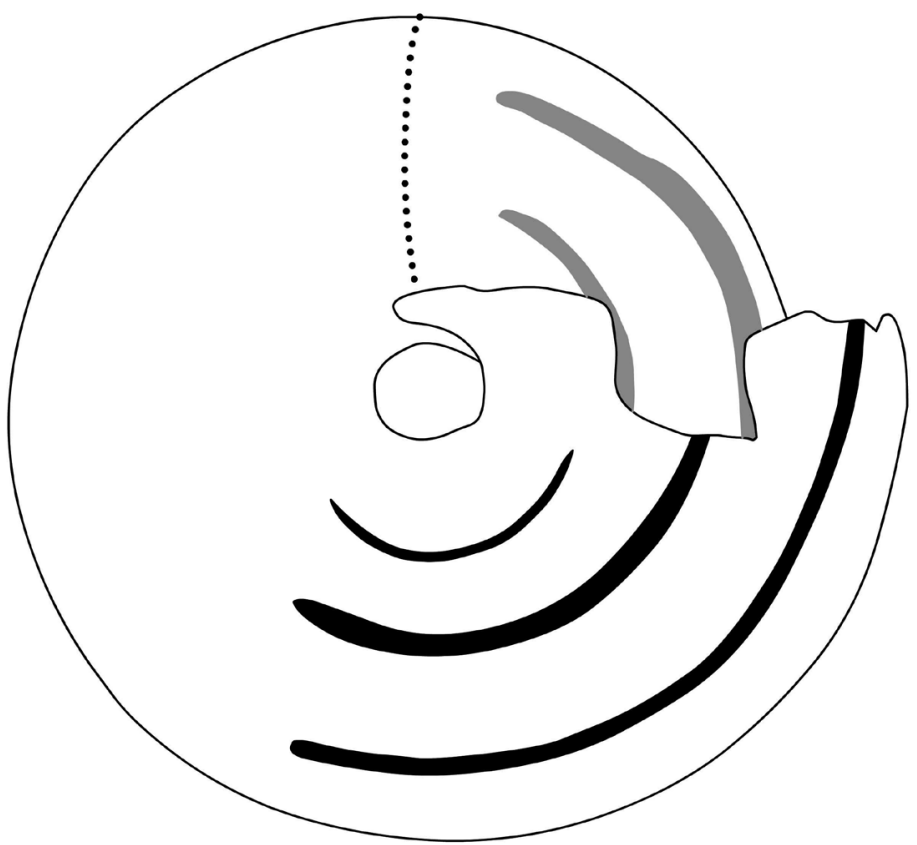

Figure 2. Drawing showing the lamellae and folds of Eostrobilops humicolus sp. n. (paratype specimen, same as on Fig. 1D-E). Black lines: basal folds; grey lines: parietal and infraparietal lamellae. Dotted line indicates the supposed position of the parietal callus.

\section{Remarks on Eostrobilops species}

Solem (1968) named three differences between the two genera: (1) Enteroplax has a raised parietal callus, lacking in Eostrobilops, (2) Enteroplax has a "peripheral thread", lacking in Eostrobilops and (3) Eostrobilops has superior serrated nodes on the parietal lamellae, missing in Enteroplax. The morphology of the callus and the periphery seem to separate the two genera well, because the raised callus is always associated with the peripheral thread and the weak callus is a characteristic feature of species which lack the peripheral thread. The serrated nodes on the lamellae, however, were not observed in at least three species (Eostrobilops infrequens, E. humicolus sp. n. and E. triptychus) which belong to Eostrobilops based on the other two characters. Therefore, the serrated node is excluded from the diagnosis of Eostrobilops. Future investigations may provide additional information on the utility of this character for the subdivision of Eostrobilops.

Eostrobilops yaeyamensis, E. taiwanica and E. kanjiokuboi have been described as Enteroplax species. However, they lack the thickened parietal callus, which is conspicuous in every Enteroplax species. Moreover, although they have a somewhat angular periphery, they lack a distinct "peripheral thread", which is also characteristic for Enteroplax. Therefore, all these three species belong to the genus Eostrobilops, as already proposed by Vermeulen (1992a) for E. yaeyamensis. 
No obvious teleoconch spiral lines are visible in the photo of the syntype of Eostrobilops diodontina, as noted in the original description (Heude 1885, Pilsbry 1927).

The palatal fold, which is approximately a quarter whorl in length and runs just above the keel in the paratype of E. kanjiokuboi (see Material and methods) was not mentioned in the original description.

Vermeulen (1992a) compared E. yaeyamensis with E. triptychus. He mentioned that E. yaeyamensis "occasionally shows an interparietalis" and "may have an interparietalis". This information is probably erroneous, because neither the original description (Habe and Chinen 1974), nor Minato (1982) mentioned an interparietalis lamella. Moreover, Vermeulen (1992a) mentioned that E. yaeyamensis has two basal folds, whereas E. triptychus possesses three. However, the description and figure of Minato (1982) describes three basal folds, and interstitial basal plicae were mentioned in the original description of E. yaeyamensis.

\section{Checklist of Enteroplax and Eostrobilops species, and their distributions (see also} Fig. 3)

Enteroplax dumogensis Vermeulen, 1992: Indonesia, North Sulawesi Island, Utara, Dumoga valley, Mount Mogogonipa (Vermeulen 1992b).

Enteroplax misoolensis (Adam \& van Benthem Jutting, 1939): Indonesia, Misool Island, near Lilinta, Waima and Fakal (Adam and van Benthem Jutting 1939, Solem 1968).

Enteroplax polyptychia (Möllendorff, 1887): Philippine Islands, Cebu and Siquijor Islands (Solem 1968).

Enteroplax quadrasi (Moellendorff, 1893): Philippine Islands, Luzon, Bohol, Mindanao islands (Moellendorff 1893, Solem 1968).

Enteroplax trochospira (Möllendorff, 1887): Philippine Islands, Cebu and Bohol islands; Indonesia: North Sulawesi (Solem 1968, Vermeulen 1992b).

Eostrobilops coreana (Pilsbry, 1927): North Korea: Pyong Yang; southeast Russia, National reserve "Kedrovaya pad" (КеАровая падь = "Cedar valley") (Pilsbry 1927, Schileyko 1984).

Eostrobilops coreana echo (Kuroda \& Miyanaga, 1939): North Korea, Soto-Kongō (outer Kumgang Mountains) (Kuroda and Miyanaga 1939).

Eostrobilops diodontina (Heude, 1885): Tchen k'eou (=Chengkou, Chongqing Province, China) (Heude 1885, Solem 1968).

Eostrobilops hirasei (Pilsbry, 1908): South Korea, Quelpart Island (Pilsbry 1908).

Eostrobilops infrequens Maassen, 2006: Vietnam, Thanh Hoa Province, Pu Luong National Park (Maassen 2006).

Eostrobilops kanjiokuboi (Minato \& Tada, 1992): Lo lo uen chuan, Tung-pu, Hsin-i shiang, Nan tou hsien, Taiwan (Minato and Tada 1992).

Eostrobilops kongoensis (Kuroda \& Miyanaga, 1939): North Korea, near Tyō-anzi, Uti-Kongō (=Kumgang Mountains; Kuroda and Miyanaga 1939). 


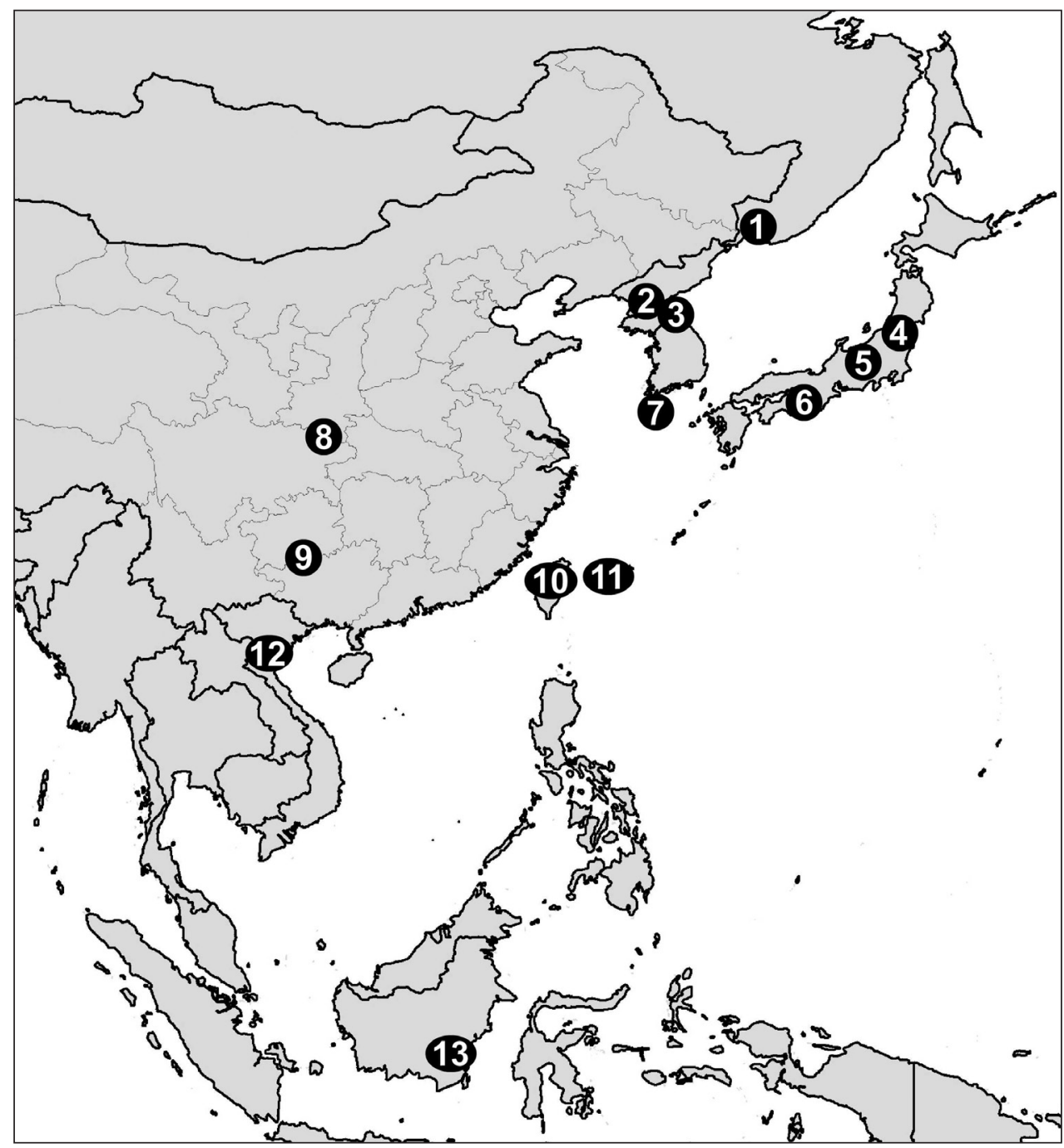

Figure 3. Distribution of Eostrobilops species. I, 2 Eostrobilops coreana (Pilsbry, 1927) 3 E. coreana echo (Kuroda \& Miyanaga, 1939) and E. kongoensis (Kuroda \& Miyanaga, 1939) 4, 5 Eostrobilops nipponica (Pilsbry, 1927) 6 E. nipponica reikoae Matsumura \& Minato, 19807 E. hirasei (Pilsbry, 1908) 8 E. diodontina (Heude, 1885) 9 E. humicolus sp. n. 10 E. kanjiokuboi (Minato \& Tada, 1992) and E. taiwanica (Minato \& Tada, 1992) I I E. yaeyamensis (Habe \& Chinen, 1974) I 2 E. infrequens Maassen, 2006 I 3 E. triptychus Vermeulen, 1992.

Eostrobilops humicolus Páll-Gergely \& Hunyadi, sp. n.: China, Guangxi, Hechi Shi, Tiane Xian, Qimu Xiang, cross towards Lahaoyan, $600 \mathrm{~m}, 24^{\circ} 51.130^{\prime} \mathrm{N}$, $107^{\circ} 11.670^{\prime} \mathrm{E}$.

Eostrobilops nipponica (Pilsbry, 1927): Japan, Yonezawa; Nagano Province (Pilsbry 1927, Minato 1975, 1982). 
Eostrobilops nipponica reikoae Matsumura \& Minato, 1980: Japan, Osaka Prefecture, Takatsuki-shi, Ibaragi-shi, Suita-shi and Minoo-shi (fourteen localities; Matsumura and Minato 1980).

Eostrobilops taiwanica (Minato \& Tada, 1992): Meifeng, Lenai shiang, Nan tou hsien, Taiwan (Minato and Tada 1992).

Eostrobilops triptychus Vermeulen, 1992: Indonesia, Borneo, Kalimantan Selatan, northwestern part of the Meratus Mountains (Vermeulen 1992a).

Eostrobilops yaeyamensis (Habe \& Chinen, 1974): Sonai, Irimote Island; Kabira, Ishigaki Island (both Yaeyama Group, Okinawa, Japan) (Habe and Chinen 1974, Vermeulen 1992a).

\section{Acknowledgements}

We are very grateful to Anatoly Schileyko, Kurt Auffenberg and Zoltán Fehér for providing literature, Jonathan Ablett (NHM), Kazunori Hasegawa (NSMT) for providing access to museums collections, Roland Farkas for his help in producing the map, Kurt Auffenberg for fine-tuning the English and Yurika Ujiie for her help for handling label data. This study was supported by scholarships from Japan Student Services Organization and Mitsubishi Corporation to BPG and Grants-in-Aid for Scientific Research (KAKENHI) from Japan Society for the Promotion of Science to T.A.

\section{References}

Adam W, van Benthem Jutting TVB (1939) Une nouvelle espèce de Ptychodon de l'Archipel Indien. Bulletin du Musée Royal d'Histoire Naturelle de Belgique 15(17): 1-3.

Ferreira CS, Dos Santos Coelho AC (1970) Novos Gastrópodes Pulmonados da Bacia Calcária de Sao José de Itaborai, RJ, Brasil. Geocronologia. Anais da Academia Brasileira de Ciências 43 (suppl.): 463-472.

Habe T, Chinen M (1974) Land Molluscan Fauna of Ishigaki and Iriomote Islands, with Notes on biogeography of Ryukyu Archipelago". Memoirs of the National Science Museum 7: 121-128, plates 15-17.

Heude RPM (1885) Mémoires Concernant l'Histoire Naturelle de l'Empire Chinois par des Pères de la Compagnie de Jésus. Notes sur les Mollusques terrestres de la vallée du Fleuve Bleu. III; Mission Catholique, Chang-Hai, 89-132. http://www.biodiversitylibrary.org/ item/106316\#page/121/mode/1up

Gude GK (1899) Armature of Helicoid landshells and new sections of Plectopylis. Science Gossip 6: 147-149. http://www.biodiversitylibrary.org/item/106135\#page/25/mode/1 up Kerney MP, Cameron RAD (1979) A Field Guide to the Land Snails of Britain and Northwest Europe. Collins, London, 288 pp.

Kuroda T, Miyanaga M (1939) New Land Shells from Northern Tyōsen (Korea). Venus 9(2): 66-85. 
Maassen WJM (2006) Four new species of terrestrial gastropods from Tonkin, North Vietnam (Gastropoda, Diplommatinidae, Strobilopsidae and Ariophantidae). Basteria 70: 13-18. Manganelli G, Delle Cave L, Giusti F (1989) Notulae Malacologicae, XLII. Strobilopsidae (Gastropoda: Pulmonata), a family new to the Villafranchian land snail fauna of the Apenninic Italy. Basteria 52: 3-13.

Matsumura I, Minato H (1998) Eostrobilops nipponica reikoae n. ssp. (Pulmonata: Strobilopsidae) from the Northern Region of Osaka, Japan. Venus 57(1): 39-47.

Miller WB, Christensen CC (1980) A new Strobilopsis (Mollusca: Strobilopsidae) from Baja California Sur, Mexico. Proceedings of the Biological Society of Washington 93: 593-596.

Minato H (1975) Genital studies of Japanese Land Snails - V. The Genitalia of Eostrobilops nipponica (Pilsbry, 1927) from Nagano Prefecture, Japan. Venus 33(4): 207-209.

Minato H (1982) Eostrobilops and Enteroplax from Japan (Strobilopsidae). Chiribotan 13(2): $28-32$.

Minato H, Tada A (1992) Two new species of the genus Enteroplax from Taiwan (Pulmonata: Strobilopsidae). Venus 51(3): 159-162. [In Japanese with English summary]

Möllendorff OF von (1887) Von den Philippinen. Jahrbücher der Deutschen Malakozoologischen Gesellschaft 14(3): 235-283. http://www.biodiversitylibrary.org/item 153960\#page/249/mode/1up

Quadras JF, Moellendorff OF de (1893) Diagnoses specierum novarum ex parte septentrionali insulae Luzon auctoribus. Nachrichtsblatt der Deutschen Malakozoologischen Gesellschaft 25(11-12): 169-184. http://www.biodiversitylibrary.org/item/53280\#page/177/ mode/1up

Pilsbry HA (1908) Two genera of land snails new to Japan and Korea. The Conchological Magazine 2(8): 39-42.

Pilsbry HA (1927-1935) Manual of Conchology, structural and systematic, with illustrations of the species. Second series: Pulmonata. Volume 28. Geographic Distribution of Pupillidae; Strobilopsidae, Valloniidae and Pleurodiscidae. Conchological department Academy of Natural Sciences of Philadelphia, Philadelphia, 28(1): 1-48 (1927), 28(2): 49-96 (1931), 28(4): 161-226 (1935). http://www.biodiversitylibrary.org/item/29025

Pilsbry HA (1948) Land Mollusca of North America (North of Mexico). Monographs of the Academy of Natural Sciences of Philadelphia 3(2): I-XLVII, 521-1113.

Schileyko AA (1984) Molluscs. Terrestrial molluscs of the suborder Pupillina of the fauna of the USSR (Gastropoda, Pulmonata, Geophila). Fanua S.S.S.R (N.S.) 130: 1-399. [In Russian]

Solem A (1968) "Ptychodon" misoolensis Adam and Van Benthem Jutting, 1939, A New Guinea Strobilopsis land snail and review of the genus Enteroplax. Veliger 11:24-30.

Solem A (1979) Biogeographic significance of land snails, Paleozoic to Recent. In: Gray J, Boucot AJ (Eds) Historical biogeography, plate tectonics, and the changing environment. Oregon State University Press, Corvallis, 277-287.

Solem A (1981) Land snail biogeography: a true snail's pace of change. In: Nelson G, Rosen DE (Eds) Vicariance and biogeography: a critique. Columbia University Press, New York, 197-237.

Tongkerd P, Lee T, Panha S, Burch JB, Foighil ÓD (2004) Molecular phylogeny of certain Thai gastrocoptine micro land snails (Stylommatophora: Pupillidae) inferred from mito- 
chondrial and ribosomal DNA sequences. Journal of Molluscan Studies 70: 139-147. doi: 10.1093/mollus/70.2.139, http://mollus.oxfordjournals.org/content/70/2/139.short

Vermeulen JJ (1992a) Notes on the non-marine molluscs of the island Borneo 4. The genus Eostrobilops (Gastropoda: Pulmonata: Strobilopsidae). Basteria 56: 65-68.

Vermeulen JJ (1992b) Two species of the genus Enteroplax (Gastropoda Pulmonata: Strobilopsidae) from Sulawesi, Indonesia. Basteria 56: 77-81.

Wade CM, Mordan PB, Naggs F (2006) Evolutionary relationships among the Pulmonate land snails and slugs (Pulmonata, Stylommatophora). Biological Journal of the Linnean Society 87: 593-610. http://onlinelibrary.wiley.com/doi/10.1111/j.1095-8312.2006.00596.x/pdf Wenz W (1923) Gastropoda Extramarina Tertiaria. In: Denier C (Ed.) Fossilium Catalogus I (17-23). W. Junk, Berlin, 1-1862. 